\title{
An Electrochemical Investigation into a Series of Tricyanovinylated Pyrrole Moieties
}

Timothy McCormac*, David Farrell, Wesley Browne** and Johannes G. Vos**

Electrochemical Technology Research Centre

Department of Applied Science

Institute of Technology Tallaght

Dublin 24

Ireland

\section{Abstract}

The electrochemical behaviour of three tri-cyanovinylated pyrrole species namely, 2tricyanovinyl-pyrrole $\left(\mathrm{C}_{4} \mathrm{H}_{4} \mathrm{~N}-\mathrm{C}_{5} \mathrm{~N}_{3}\right)$, 2-tricyanovinyl-N-methylpyrrole $\left(\mathrm{C}_{5} \mathrm{H}_{6} \mathrm{~N}-\mathrm{C}_{5} \mathrm{~N}_{3}\right)$ and 2tricyanovinyl-N-phenylpyrrole $\left(\mathrm{C}_{10} \mathrm{H}_{8} \mathrm{~N}-\mathrm{C}_{5} \mathrm{~N}_{3}\right)$, has been studied. All compounds were found to exhibit both an irreversible oxidation at more positive potentials compared to the unsubstituted monomer species and a reversible reduction redox couple associated with reduction of the co-ordinated cyano ligands. The latter reductions of the tricyanovinylated compounds to their radical anions at platinum, carbon and gold electrodes in acetonitrile solution have been studied by cyclic voltammetry, using a variety of supporting electrolytes. The half-wave potentials for each compound were found to be dependent upon the supporting electrolyte but independent of the nature of the electrode surface. This is attributed to ion-pairing between the anions and the alkali metal cations. The reduction based redox processes for the $\mathrm{C}_{10} \mathrm{H}_{8} \mathrm{~N}-\mathrm{C}_{5} \mathrm{~N}_{3}$ and $\mathrm{C}_{5} \mathrm{H}_{6} \mathrm{~N}-\mathrm{C}_{5} \mathrm{~N}_{3}$ compounds were found to be facile in nature and independent of both the nature of the electrolyte and electrode surface. However the reduction of $\mathrm{C}_{4} \mathrm{H}_{4} \mathrm{~N}-\mathrm{C}_{5} \mathrm{~N}_{3}$ was found to be irreversible in nature. Attempts were made to elucidate, by both electrochemical and spectroscopic means, the structure of the products obtained upon oxidation of the tricyanovinylated compounds.

Keywords: pyrrole, tricyanovinylated, heterogeneous rate constants, irreversible oxidation

* to whom correspondence should be addressed 
** School of Chemical Sciences, Dublin City University, Dublin 9, Ireland.

\section{Introduction}

Polypyrrole is one of the most studied of all known conducting polymer films [1-4]. It has been electrochemically deposited along with a range of anions such as $\left[\mathrm{Fe}(\mathrm{CN})_{6}\right]^{4}[5]$, dodecylbenzenesulphonate[6,7], and cobalt derivatives[8-10]. Generally species incorporated into conducting polymers have existed as anions in solution. Previously Blackwood et al [11] incorporated the well-known electron acceptor molecule, tetracyanoquinodimethane (TCNQ), into various conducting polypyrrole films. The reason this was attempted was the due to the employment of conducting polypyrrole films for gas sensing. The presence of the electron acceptor within the polymeric film would enable the authors to elucidate when the gas molecule interacts with the polymeric backbone is it acting as an electron acceptor or donor. Also polymer films doped with TCNQ have been studied by reflectance infrared spectroscopy when deposited in the presence of $\mathrm{BF}_{4}{ }^{-}$[12]. As a result of the work by these authors[11,12] and our interest in the use of conducting polymeric films within the field of gas sensing, we attempted to incorporate another well-known electron acceptor, tetracyanoethylene (TCNE) the strong $\pi$-acid, into a variety of polypyrrole films during the electropolymerisation step. Investigations within our group have shown that the TCNE molecule attacks the pyrrole ring through the $\alpha$ - position leading to tricyanovinylated products, as shown in Figure 1 .

Previously we have isolated and characterised these compounds [13]. In this report we study the electrochemical behaviour of these tricyanovinylated compounds in detail. Their reduction to their radical anions is discussed with the effect of different supporting electrolyte cations and electrode surface on the voltammetry being investigated. Also the oxidation of the compounds has been studied by both electrochemical and spectroscopic means. 


\section{Experimental}

\subsection{Materials}

The tricyanovinylated pyrrole moieties, namely $\mathrm{C}_{4} \mathrm{H}_{4} \mathrm{~N}-\mathrm{C}_{5} \mathrm{~N}_{3}, \mathrm{C}_{5} \mathrm{H}_{7} \mathrm{~N}-\mathrm{C}_{5} \mathrm{~N}_{3}$ and $\mathrm{C}_{10} \mathrm{H} \mathrm{H}_{8} \mathrm{~N}-\mathrm{C}_{5} \mathrm{~N}_{3}$ were synthesised according to the literature [13]. They were characterised by both spectroscopic $\left(\mathrm{H}^{1} / \mathrm{C}^{13} \mathrm{NMR}, \mathrm{IR}, \mathrm{UV} / \mathrm{Vis}\right)$ and electrochemical techniques. All other chemicals were of reagent grade and used as received. Acetonitrile (HPLC grade water content $0.005 \%$ ) was dried by storing over anhydrous calcium chloride for 24 hours and then over $4 \AA$ molecular sieves, which had been activated by placing in an oven at $523 \mathrm{~K}$ overnight.

\subsection{Apparatus and Procedures}

Electrochemical experiments were performed in a single compartment three-electrode cell. The reference electrode employed was a silver wire in contact with an acetonitrile solution of $\mathrm{AgNO}_{3}(0.01 \mathrm{M})$ and $0.1 \mathrm{M}$ of the same supporting electrolyte as employed in the cell. $\mathrm{A}$ variety of working electrodes were employed, namely a vitreous carbon $(\mathrm{d}=3 \mathrm{~mm})$, a teflon shrouded platinum disc $(\mathrm{d}=2.0 \mathrm{~mm})$ and a teflon shrouded gold disc $(\mathrm{d}=2.0 \mathrm{~mm})$ electrode. The working electrodes were polished first with $0.05 \mu \mathrm{m}$ alumina, after which they were washed thoroughly with deionised water and acetone prior to use. Platinum working microelectrodes $(25 \mu \mathrm{m})$ were employed as the working electrode for the fast scan rate studies of the oxidative processes. These electrodes were polished successively with 1.0, 0.3 and $0.05 \mu \mathrm{m}$ aqueous alumina slurries and sonicated in distilled water and rinsed with acetone after each polishing step. The electrodes were then electrochemically cleaned by cycling in deoxygenated $0.1 \mathrm{M} \mathrm{H}_{2} \mathrm{SO}_{4}$ from -0.3 to $1.5 \mathrm{~V}$ until a voltammogram characteristic of a clean platinum electrode was obtained. Before use, the electrodes were cycled in $0.1 \mathrm{M}$ $\mathrm{LiClO}_{4}$ until hydrogen desorption was complete. The auxiliary electrode material was a platinum wire. A CH 750A bipotentiostat was employed for all electrochemical experiments. The iR drop and RC time constants for each system under study was measured by the application of a small potential perturbation of $50 \mathrm{mV}$ at $0.0 \mathrm{~V}\left(\mathrm{vs} \mathrm{Ag} / \mathrm{Ag}^{+}\right)$with the iR drop hence being compensated for by the positive feedback circuitry of the bipotentiostat. All cyclic voltammograms were background subtracted. All solutions were prepared with dry 
HPLC grade acetonitrile and degassed with pure argon for 15 min prior to electrochemical experiments. All voltammetric experiments were carried out at room temperature, unless otherwise stated. All potentials in this paper are given with respect to the $\mathrm{Ag} /\left(0.01 \mathrm{M} \mathrm{Ag}^{+}\right)$ reference electrode, unless otherwise stated. For the bulk electrolysis experiments a large surface area carbon electrode was employed. Spectroelectrochemistry was carried out using a home-made Pyrex glass thin-layer cell $(1 \mathrm{~mm})$, a platinum gauze as the working electrode, and a platinum wire as the counter electrode. The electrolyte used was $0.1 \mathrm{M} \mathrm{LiClO}_{4}$ in acetonitrile and the UV-Vis-NIR spectra were recorded using the Shimadzu 3100 UV-NIR spectrometer interfaced to an Elonex PC433 personnel computer. The working electrode was held at the required potential during the spectral scan using an EG\&G PAR model 362 scanning potentiostat. 


\section{Results and Discussion}

\subsection{Basic Electrochemical behaviour}

Fig 2(a) - (c) shows the representative cyclic voltammograms obtained, on a platinum working electrode, for $1 \mathrm{mM}$ acetonitrile solutions of the tricyanovinylated compounds. Upon reductive scanning, the voltammograms for the $\mathrm{C}_{5} \mathrm{H}_{7} \mathrm{~N}-\mathrm{C}_{5} \mathrm{~N}_{3}$ and $\mathrm{C}_{10} \mathrm{H}_{8} \mathrm{~N}-\mathrm{C}_{5} \mathrm{~N}_{3}$ species, figures $2(b)$ and 2(c), respectively, show two peaks, $P_{c}(1)$ and $P_{a}(1)$ for the quasi-reversible one-electron reduction of the cyano ligands [14]. The latter were determined to be oneelectron processes by means of bulk electrolysis and by comparing the redox behaviour of these tricyanovinylated pyrrole species to that of the ferrocene/ferrocenium couple. The corresponding one electron reduction of the $\mathrm{C}_{4} \mathrm{H}_{4} \mathrm{~N}-\mathrm{C}_{5} \mathrm{~N}_{3}$ species is irreversible in nature, as seen in Figure 2(a). It is believed that these reductive processes correspond to the reduction of the $\mathrm{C}_{5} \mathrm{~N}_{3}$ part of the molecules as they are not present for any of the unsubstituted monomer species alone in acetonitrile. In addition to this it occurs in a similar domain to the reductions of the TCNE molecule in acetonitrile [14]. Upon oxidation an irreversible oxidation peak, $\mathrm{P}_{\mathrm{a}}(2)$, appears for all compounds. These peaks correspond to the irreversible oxidation of the monomer unit of each compound, with their position being further positive compared to the unsubstituted monomer. An interesting point to note is that upon continuous scanning in a positive direction, between $0 \mathrm{~V}$ and $+1.7 \mathrm{~V}$, no polymerisation of the compounds is seen to occur with no polymer deposition upon the electrode. This is due to the fact that one of the $\alpha$-positions of the monomer rings are substituted with the $\mathrm{C}_{5} \mathrm{~N}_{3}$ group, thereby blocking any possible polymerisation mechanism. Upon scan reversal, after oxidation, to more negative potentials than $\mathrm{OV}$, a new reduction peak, $\mathrm{p}_{\mathrm{c}}(2)$, is observed at approximately $-0.25 \mathrm{~V}$. This occurs for all compounds however it is weak in character for the $\mathrm{C}_{10} \mathrm{H}_{8} \mathrm{~N}-\mathrm{C}_{5} \mathrm{~N}_{3}$ species, as seen in figure 2(c), but the current for the process increases upon continuous scanning through the oxidation wave. The appearance of this new reduction wave can be attributed to the associated electrochemistry of the product formed upon oxidation of the tricyanovinylated products. However another possibility is that the reverse scans are consistent with the liberation of protons accompanying electro-oxidation of pyrrole monomers

[15]. As can be seen all tricyanovinylated compounds exhibit similar behaviour. To investigate the possibility that the oxidation wave is connected to a chemical follow up 
reaction, namely an EC mechanism, the behaviour of the irreversible wave as a function of both scan rate and temperature was investigated. It was hoped that by either lowering the temperature or raising the scan rate that the chemical follow up reaction could be stopped and a reversible electrochemical redox process would occur. Cyclic voltammograms were run at the temperatures $291,273,253,238$ and $228 \mathrm{~K}$ at scan rates of both 0.5 and $5.0 \mathrm{~V} \mathrm{~s}^{-1}$. However for all compounds the voltammograms were nearly identical to those in Figure 2, that is the oxidation was still irreversible in nature with the redox activity of the product still being present. A platinum microelectrode was employed and oxidative cyclic voltammograms for all compounds were recorded at scan rates from 0.025 to $200 \mathrm{~V} \mathrm{~s}^{-1}$. However even at the highest scan rate the electrooxidation of the pyrrole moieties remains irreversible in nature. One possibility is that the scan rates employed were too low and that much higher scan rates will needed to be employed to elucidate the mechanism of the oxidation reaction and to see if any reversibility can be attained at higher scan rates. This can be achieved through the use of specialist high speed electrochemical equipment, this will be the aim of future work concerning these molecules.

\subsection{Spectroelectrochemistry}

Spectroelectrochemical experiments were performed upon all three compounds both upon oxidation and reduction. Figure 3(a) - (c) illustrates the spectra obtained for the oxidation of the $\mathrm{C}_{4} \mathrm{H}_{4} \mathrm{~N}-\mathrm{C}_{5} \mathrm{~N}_{3}, \mathrm{C}_{5} \mathrm{H}_{6} \mathrm{~N}-\mathrm{C}_{5} \mathrm{~N}_{3}$ and $\mathrm{C}_{10} \mathrm{H}_{8} \mathrm{~N}-\mathrm{C}_{5} \mathrm{~N}_{3}$ moieties at +2.0 Volts in dry MeCN $0.1 \mathrm{M}$ $\mathrm{LiClO}_{4}$ solutions, respectively. For the $\mathrm{C}_{5} \mathrm{H}_{6} \mathrm{~N}-\mathrm{C}_{5} \mathrm{~N}_{3}$ moiety what is evident is the disappearance of the band at 390nm for the parent molecule and the growth of two new bands at $\sim 290 \mathrm{~nm}$ and $\sim 245 \mathrm{~nm}$, with the latter being weak in character, for the oxidised product. As can be seen the $\mathrm{C}_{4} \mathrm{H}_{4} \mathrm{~N}-\mathrm{C}_{5} \mathrm{~N}_{3}$ and $\mathrm{C}_{10} \mathrm{H}_{8} \mathrm{~N}-\mathrm{C}_{5} \mathrm{~N}_{3}$ species both show a similar decrease in absorption above wavelengths of $300 \mathrm{~nm}$, that is bands associated with the parent molecules, and the increase in absorption at wavelengths below $300 \mathrm{~nm}$. All compounds exhibited a similar change in colour upon oxidation from yellow to red. This shift to lower wavelengths upon oxidation rules out the possibility of dimer formation upon oxidation, as if the conjugation length of the system was being increased there should be a shift to higher wavelengths. Reductive spectroelectrochemical experiments for all 
compounds were also performed and the results for all experiments are summarised in table 1.

\subsection{Controlled potential bulk electrolysis}

Exhaustive bulk electrolysis experiments were also performed to try and elucidate the identity of product obtained upon electrooxidation. Attempts were made to isolate the final oxidative products by a variety of conventional means with both ${ }^{1} \mathrm{H}$ and ${ }^{13} \mathrm{C}$ NMR spectroscopy being employed to elucidate the identity of the final oxidised products. Interestingly when spectrum were run of solutions of the final oxidised products no spectrum were obtained, neither that associated with the original parent, or the oxidised compounds. It was originally thought that perhaps the concentration of the final oxidative product was too low to obtain qualitative spectra for structure elucidation. Attempts to overcome this by means of increasing the concentration of the parent molecule before bulk electrolysis, increasing the number of scans and running time of data acquisition in the spectroscopic experiments all proved unsuccessful. The absence of any spectral details point to the formation of a radical species, which could be generated by the electrooxidation, as it is well known that electrooxidation of unsubstituted pyrrole generates a radical cation which leads to polymerisation. Formation of a radical upon oxidation would also account for the difficulty in its isolation. It should be stressed that even though no spectral details could be obtained for the product, the cyclic voltammograms of the bulk electrolysis solutions revealed that the original electrochemistry associated with the starting compounds had disappeared and that the electrochemistry associated with the final oxidised products was present, as seen in Figure 2. Attempts to try and overcome these problems are currently underway within our group. It is envisaged that this work shall be the subject of a future publication with the employment of Electron Paramagnetic Resonance (EPR) being ideal to elucidate if radical species are indeed being formed.

\subsection{Influence of background electrolyte}

Table 2 summarises the electrochemical peak potentials for both the unsubstituted monomer species and the synthesised tricyanovinylated products. What is evident is that the monomer 
oxidation in the tricyanovinylated compounds has shifted to more positive potentials. This positive shift is characteristic of substituted pyrrole species [15]. Table 3 summarises in detail the peak potentials and peak separations for the reduction waves of the tricyanovinylated products, as a function of the nature of the electrolyte and electrode surface. What is evident is that the peak potentials and hence the half wave potentials for the reductive processes were dependent upon the nature of the supporting electrolyte but independent of electrode surface. For example the half wave potentials of the redox couple for the $\mathrm{C}_{10} \mathrm{H}_{8} \mathrm{~N}-\mathrm{C}_{5} \mathrm{~N}_{3}$ species at a bare platinum electrode were $-0.985 \mathrm{~V}$ with TBAP $(0.1 \mathrm{M})$ as supporting electrolyte, $-0.947 \mathrm{~V}$ with $\mathrm{NaClO}_{4}(0.1 \mathrm{M})$ and $-0.910 \mathrm{~V}$ with $\mathrm{LiClO}_{4}(0.1 \mathrm{M})$. This can be attributed to ion-pairing between the anionic species formed upon reduction and alkali metal cations in the supporting electrolyte. This interaction would lower the Gibbs energy of the electron-transfer reaction by stabilising the product of the reaction, and hence as a result the reduction would take place at less negative potentials. As can be seen there is a positive shift in $E_{1 / 2}$ as the large organic cation, tetrabutylammonium (TBA) is replaced by the alkali metal cations of $\mathrm{Li}^{+}$and $\mathrm{Na}^{+}$as $\Delta \mathrm{G}^{\circ}$ becomes more negative for the reductive step. It can be seen that the anionic species are more stabilised by the $\mathrm{Li}^{+}$cations more than the $\mathrm{Na}^{+}$cations, this thereby indicates that contact ion-pairs rather than solvent separated ion-pairs are formed. It is important to stress that all tricyanovinylated species exhibited this behaviour irrespective of the nature of the electrode surface, as evidenced by the data in Table 3.

\subsection{Heterogeneous rate constant determination}

Table 4 lists diffusion coefficients and the kinetic data for the reduction of the tricyanovinylated compounds. The diffusion coefficients were calculated by employing the Randles-Sevcik equation for a reversible process

$$
\mathrm{i}_{\mathrm{p}, \mathrm{c}}=2.69 \times 10^{5} \mathrm{n}^{3 / 2} A C^{0} \mathrm{D}_{0}{ }^{1 / 2} v^{1 / 2}
$$

The values obtained were seen to be independent of the supporting electrolyte and they agree with typical values obtained for solution phase species. For example the value for the parent TCNE molecule was previously reported as $1.91 \times 10^{-5} \mathrm{~cm}^{2} \mathrm{~s}^{-1}$ [14]. For both the $\mathrm{C}_{5} \mathrm{H}_{6} \mathrm{~N}$ - 
$\mathrm{C}_{5} \mathrm{~N}_{3}$ and $\mathrm{C}_{10} \mathrm{H}_{8} \mathrm{~N}-\mathrm{C}_{5} \mathrm{~N}_{3}$ systems, $\mathrm{k}_{\mathrm{s}}$ was calculated from the variation of peak separation, $\Delta \mathrm{E}_{\mathrm{p}}$, with sweep rate, $v$, using the method of Nicholson [16] for a quasi-reversible electron transfer reaction. The resulting $\mathrm{k}_{\mathrm{s}}$ values are shown in Table 4 , and they were found to be independent of scan rate over the range of $0.1-0.6 \mathrm{Vs}^{-1}$. It is important to stress that these values for $\mathrm{k}_{\mathrm{s}}$ did not vary significantly with sweep rate. The reduction process for these two systems showed simple quasi-reversible behaviour up to a scan rate of $1 \mathrm{Vs}^{-1}$. At $0.1 \mathrm{Vs}^{-1}$ the cathodic and anodic peak potentials were separated by 60 to $70 \mathrm{mV}$, which is close to the theoretical value of $59 \mathrm{mV}$ for a reversible one-electron reduction, the ratio of the anodic and cathodic peak currents was also close to 1.0 with the ratio $I_{p, c} / v^{1 / 2}$ being independent of scan rate.

The values obtained for the heterogeneous rate constants point to all the reduction processes being facile in nature and of similar value to those obtained for the first reduction process of the parent TCNE molecule [14]. Also the $\mathrm{k}_{\mathrm{s}}$ for the reduction processes of all the synthesised molecules do not greatly depend upon either the nature of the electrode surface or the electrolyte. The reason for investigating this was that the rate of the second reduction process of TCNE was seen to depend significantly upon the type of electrode surface being employed, with several orders of magnitude of a difference being observed [14]. The effects of both the nature of the electrolyte and electrode material, upon the rate constants for the reduction processes was fully investigated (Table 4). What is evident from the results is that increasing the size of the cation has no effect upon the standard rate constants. Previously it has been shown for aprotic systems [17] that the as the size of the cation is increased there is a decrease in the standard rate constants. This has been attributed to either blockage of the electrode surface by the specific adsorption of the bulky cations or due to the variation of the outer Helmholtz plane (OHP) with cation size, with the latter affecting the rate of the outer sphere electron transfer reaction.

The reductive process for the 2-tricyanovinyl-pyrrole $\left(\mathrm{C}_{4} \mathrm{H}_{4} \mathrm{~N}-\mathrm{C}_{5} \mathrm{~N}_{3}\right)$ species was assumed to be completely irreversible in the majority of electrolytes, however some quasi-reversibility was observed in 0.1M TBAP. Tafel plots were constructed according to the method described 
in literature [16] and the values for both the heterogeneous rate constant and the exchange coefficient being obtained from the intercept and slope, respectively. $\mathrm{E}^{\mathrm{O}^{\prime}}$ being obtained from a cyclic voltammogram at slow scan rates (i.e. $50 \mathrm{mVs}^{-1}$ ) when the compound exhibits quasireversible behaviour. What is apparent from the results for $\mathrm{C}_{4} \mathrm{H}_{4} \mathrm{~N}-\mathrm{C}_{5} \mathrm{~N}_{3}$ in Table 4 is that the heterogeneous rate constants, $\mathrm{k}_{\mathrm{s}}$, obtained for this species are all in good agreement with one another, being independent of both electrolyte and electrode surface with the values for the $\mathrm{C}_{4} \mathrm{H}_{4} \mathrm{~N}-\mathrm{C}_{5} \mathrm{~N}_{3}$ species, being an order of magnitude lower compared to the $\mathrm{k}_{\mathrm{s}}$ values for the other tricyanovinylated products. This thereby illustrates the slower kinetics associated with the reductive processes of the 2-tricyanovinyl-pyrrole species. To investigate the possibility that the irreversible reduction wave is connected to a chemical follow up reaction, namely an EC mechanism, the behaviour of the irreversible wave as a function of scan rate was investigated. It was hoped that by increasing the scan rate that the chemical follow up reaction could be stopped and a reversible electrochemical redox process would occur. A platinum microelectrode was employed and reductive cyclic voltammograms for all compounds were recorded at scan rates from 0.050 to $10 \mathrm{~V} \mathrm{~s}^{-1}$. However even at the faster scan rates the reduction of the pyrrole compound remains irreversible and in fact at lower scan rates some reversibility is observed. This latter point and also that there is not the expected shift in the $E_{p, c}$ as a function of scan rate that would be expected if an EC mechanism was present, lead us to conclude that there is no chemical follow up reaction.

Future work will revolve around trying to overcome the problems mentioned concerning the isolation and characterisation of the final oxidative products after exhaustive bulk electrolysis, with the employment of both fast scan voltammetry and EPR being central to this future work.

\section{Conclusion}


There are several findings within this article these include:

(a) 2-tricyanovinyl-pyrrole $\left(\mathrm{C}_{4} \mathrm{H}_{4} \mathrm{~N}-\mathrm{C}_{5} \mathrm{~N}_{3}\right)$, 2-tricyanovinyl-N-methylpyrrole $\left(\mathrm{C}_{5} \mathrm{H}_{6} \mathrm{~N}-\mathrm{C}_{5} \mathrm{~N}_{3}\right)$ and 2-tricyanovinyl-N-phenylpyrrole $\left(\mathrm{C}_{10} \mathrm{H}_{8} \mathrm{~N}-\mathrm{C}_{5} \mathrm{~N}_{3}\right)$, form strongly bound contact ion pairs with alkali metal cations in acetonitrile, with ion-pairing being stronger for $\mathrm{Li}^{+}$than for the $\mathrm{Na}^{+}$cation.

(b) The reductions of 2-tricyanovinyl-N-methylpyrrole $\left(\mathrm{C}_{5} \mathrm{H}_{6} \mathrm{~N}-\mathrm{C}_{5} \mathrm{~N}_{3}\right)$ and 2-tricyanovinyl-Nphenylpyrrole $\left(\mathrm{C}_{10} \mathrm{H}_{8} \mathrm{~N}-\mathrm{C}_{5} \mathrm{~N}_{3}\right)$, are reversible in nature up to $1000 \mathrm{mVs}^{-1}$, with the kinetics being independent of electrode surface and nature of electrolyte.

(c) The reduction of 2-tricyanovinyl-pyrrole $\left(\mathrm{C}_{4} \mathrm{H}_{4} \mathrm{~N}-\mathrm{C}_{5} \mathrm{~N}_{3}\right)$ is irreversible in nature at all electrode surfaces and in all electrolytes.

(d) The oxidative products of all the tricyanovinylated compounds possess UV/Vis spectra and redox electrochemistry in their own rite, with their identity unclear but radical formation is a strong possibility.

\section{Acknowledgements}

Financial support obtained through the Irish Graduate Training Programme TA 021999 is acknowledged. The authors would like to thank Drs Brian Murray and Fintan Kelleher (Institute of Technology Tallaght) for useful discussions concerning the NMR data. 


\section{References}

1. K. Keijikanazawa, A.F. Diaz, W.D. Gill, P.M. Grant, G.B. Street, G.P. Gardini and J.F. Kwak, Synth. Metals. 1979/1980, 1, 329.

2. G. Bidan, Sensors and Actuators B. 1992, 6, 45.

3. J. Tamm, A. Alumaa, A. Hallik, V. Sammelselg, J. Electroanal. Chem. 1998, 448, 25.

4. Z. Cai, C.R. Martin, J. Electroanal. Chem. 1991, 300, 35.

5. W. Breen, J. Cassidy, M.E.G. Lyons, J. Electroanal. Chem. 1991, 297, 445.

6. T. McCormac, W. Breen, A. McGee, J.F. Cassidy, M.E.G. Lyons, Electroanalysis. 1995, $7,287$.

7. M.E.G. Lyons, W. Breens, J. Cassidy, J. Chem. Soc., Faraday Trans. 1991, 87,115.

8. I. De Gregori, M. Carrier, A. Deronzier, J.C. Moutet, F. Bedioui, J. Devynck, J. Chem. Soc., Faraday Trans. 1992, 88,1567.

9. O. Ikeda, K. Okabayashi, N. Yoshida, H. Tamura, J. Electroanal. Chem. 1985, 191,157.

10. R. Jiang, S. Dong, J. Electroanal. Chem. 1988, 246,101.

11. D. Blackwood, M. Josowicz, J. Phys. Chem. 1991, 95,493.

12. H. Kato, O. Nishikawa, T. Matsui, S. Honma, H. Kokado, J. Phys. Chem. 1991, 95, 6011.

13. T. McCormac, D. Farrell, Electrochimica Acta, 2001, 46, 3287.

14. S.B. Khoo, J.K. Foley, S. Pons, J. Electroanal. Chem. 1986, 215, 273.

15. F. Daire, F. Bedioui, J. Devynck, C. Bied-Charreton, J. Electroanal. Chem. 1987, 224, 95.

16. A. J. Bard, L. R. Faulkner, Electrochemical Methods J. Wiley 1980.

17. H. Matsuda, Bull. Chem. Soc. Jpn. 1980, 53, 3439. 


\section{Figure Legends}

Figure 1. Chemical Structures of Synthesised Tricyanovinylated Pyrrole Derivatives

(a) 2-(tricyanovinyl) pyrrole, (b) 2-(tricyanovinyl) N-methylpyrrole and (c) 2(tricyanovinyl) N-phenylpyrrole

Figure 2. Cyclic voltammograms of the tricyanovinylated products $(1 \mathrm{mM})$ in a $0.1 \mathrm{M}$ $\mathrm{LiClO}_{4}$ acetonitrile solution. Scan rate $=100 \mathrm{mV} / \mathrm{s}$, Pt working electrode.

(a) 2-(tricyanovinyl) pyrrole, (b) 2-(tricyanovinyl) $\mathrm{N}$-methylpyrrole and (c) 2(tricyanovinyl) N-phenylpyrrole.

Figure 3. Spectroelectrochemical spectra upon oxidation at $2.2 \mathrm{~V}$ vs. $\mathrm{Ag} / \mathrm{AgCl}$ for (a) 2 (tricyanovinyl) pyrrole, (b) 2-(tricyanovinyl) N-methylpyrrole and (c) 2(tricyanovinyl) N-phenylpyrrole. 
Table 1: UV/Vis data for parent, oxidised and reduced tricyanovinylated pyrrole based moieties. $(\mathrm{sh}=$ shoulder $)$

\begin{tabular}{rc}
\hline Compound & UV/Vis Spectrum Details \\
\hline $\mathbf{C}_{4} \mathbf{H}_{4} \mathbf{N}-\mathbf{C}_{5} \mathbf{N}_{3}$ & $250 \mathrm{~nm}\left(\lambda_{\max }\right), 240 \mathrm{~nm}(\mathrm{sh})$ \\
Oxidised @ +2.0 & $220 \mathrm{~nm}\left(\lambda_{\max }\right), 275 \mathrm{~nm}$ \\
Reduced @ -1.7V & \\
$\mathbf{C}_{5} \mathbf{H}_{6} \mathbf{N}-\mathbf{C}_{5} \mathbf{N}_{3}$ & $295 \mathrm{~nm}\left(\lambda_{\max }\right), 240 \mathrm{~nm}(\mathrm{sh})$ \\
Oxidised @ +2.0V & $\cong 220 \mathrm{~nm}\left(\lambda_{\max }\right)$ \\
Reduced @ -1.7V & \\
$\mathbf{C}_{10} \mathbf{H}_{8} \mathbf{N}-\mathbf{C}_{5} \mathbf{N}_{3}$ & $240 \mathrm{~nm}\left(\lambda_{\max }\right)$ \\
Oxidised @ +2.0V & $255 \mathrm{~nm}\left(\lambda_{\max }\right)$ \\
Reduced @ -1.7V & \\
\hline
\end{tabular}

Table 2: Peak and half wave potentials for the redox processes of the tricyanovinylated pyrrole based moieties in $0.1 \mathrm{M} \mathrm{LiClO}_{4} \mathrm{MeCN} @ \mathrm{Pt}$ electrode. Scan rate $=100 \mathrm{mVs}^{-1}$.

\begin{tabular}{|c|c|c|c|c|}
\hline Product & $\begin{array}{c}\text { Ep,a } \\
\text { (Volts) }\end{array}$ & $\begin{array}{c}\text { Ep,c * } \\
\text { (Volts) }\end{array}$ & $\begin{array}{l}\text { Ep,a * } \\
\text { (Volts) }\end{array}$ & $\begin{array}{c}E_{1 / 2} \\
\text { (Volts) }\end{array}$ \\
\hline $\begin{array}{l}\text { Pyrrole } \\
\left(\mathrm{C}_{4} \mathrm{H}_{5} \mathrm{~N}\right)\end{array}$ & +1.110 & ---------- & --.------ & - \\
\hline $\begin{array}{c}\mathrm{N} \text {-methylpyrrole } \\
\left(\mathrm{C}_{5} \mathrm{H}_{8} \mathrm{~N}\right)\end{array}$ & +1.160 & ---- & & \\
\hline $\begin{array}{c}\text { N-Phenylpyrrole } \\
\left(\mathrm{C}_{10} \mathrm{H}_{0} \mathrm{~N}\right)\end{array}$ & +1.460 & ------------ & $\ldots$ & ..-- \\
\hline $\mathrm{C}_{4} \mathrm{H}_{4} \mathrm{~N}-\mathrm{C}_{5} \mathrm{~N}_{3}$ & +1.509 & $-0.913^{* *}$ & - & ---------- \\
\hline $\mathrm{C}_{5} \mathrm{H}_{6} \mathrm{~N}-\mathrm{C}_{5} \mathrm{~N}_{3}$ & +1.569 & -1.026 & -0.954 & -0.990 \\
\hline $\mathrm{C}_{10} \mathrm{H}_{8} \mathrm{~N}-\mathrm{C}_{5} \mathrm{~N}_{3}$ & +1.696 & -0.954 & -0.860 & -0.907 \\
\hline
\end{tabular}

* Upon reduction of the compound

${ }^{*}$ Irreversible in nature at this scan rate 
Table 3: Peak potentials $\left(E_{p, a}, E_{p, c}\right)$, half wave potentials $\left(E_{1 / 2}\right)$ and peak separations $\left(\Delta E_{p}\right)$ for the reductive redox processes of the tricyanovinylated pyrrole products at $100 \mathrm{mV} \mathrm{s}^{-1}$.

\begin{tabular}{|c|c|c|c|c|c|c|}
\hline Compound & Electrolyte & Electrode & $\begin{array}{c}E_{p, c} \\
\text { (Volts) }\end{array}$ & $\begin{array}{c}E_{p, a} \\
\text { (Volts) }\end{array}$ & $\begin{array}{c}E_{1 / 2} \\
\text { (Volts) }\end{array}$ & $\underset{\text { (millivolts) }}{\Delta \mathrm{E}_{\mathrm{p}}}$ \\
\hline $\mathrm{C}_{4} \mathrm{H}_{4} \mathrm{~N}-\mathrm{C}_{5} \mathrm{~N}_{3}{ }^{*}$ & $\mathrm{LiClO}_{4}$ & $\begin{array}{l}\text { Carbon } \\
\text { Gold } \\
\text { Platinum }\end{array}$ & $\begin{array}{l}-0.913 \\
-0.912 \\
-0.920\end{array}$ & $\begin{array}{l}-0.806 \\
-0.821 \\
-0.813\end{array}$ & $\begin{array}{l}-0.860 \\
-0.867 \\
-0.867\end{array}$ & $\begin{array}{c}107 \\
91 \\
107\end{array}$ \\
\hline $\mathrm{C}_{4} \mathrm{H}_{4} \mathrm{~N}-\mathrm{C}_{5} \mathrm{~N}_{3}{ }^{*}$ & $\mathrm{NaClO}_{4}$ & $\begin{array}{c}\text { Carbon } \\
\text { Gold } \\
\text { Platinum }\end{array}$ & $\begin{array}{l}-0.954 \\
-0.948 \\
-0.947\end{array}$ & $\begin{array}{l}-0.866 \\
-0.862 \\
-0.866\end{array}$ & $\begin{array}{l}-0.910 \\
-0.913 \\
-0.907\end{array}$ & $\begin{array}{l}88 \\
93 \\
81\end{array}$ \\
\hline $\mathrm{C}_{4} \mathrm{H}_{4} \mathrm{~N}-\mathrm{C}_{5} \mathrm{~N}_{3}$ & $\mathrm{TBAClO}_{4}$ & $\begin{array}{c}\text { Carbon } \\
\text { Gold } \\
\text { Platinum }\end{array}$ & $\begin{array}{l}-0.984 \\
-0.974 \\
-0.964\end{array}$ & $\begin{array}{l}-0.884 \\
-0.910 \\
-0.880\end{array}$ & $\begin{array}{l}-0.945 \\
-0.942 \\
-0.933\end{array}$ & $\begin{array}{c}111 \\
64 \\
84\end{array}$ \\
\hline $\mathrm{C}_{5} \mathrm{H}_{6} \mathrm{~N}-\mathrm{C}_{5} \mathrm{~N}_{3}$ & $\mathrm{LiClO}_{4}$ & $\begin{array}{l}\text { Carbon } \\
\text { Gold } \\
\text { Platinum }\end{array}$ & $\begin{array}{l}-1.031 \\
-1.039 \\
-1.033\end{array}$ & $\begin{array}{l}-0.977 \\
-0.983 \\
-0.974\end{array}$ & $\begin{array}{l}-1.004 \\
-1.011 \\
-1.003\end{array}$ & $\begin{array}{l}54 \\
56 \\
59\end{array}$ \\
\hline $\mathrm{C}_{5} \mathrm{H}_{6} \mathrm{~N}-\mathrm{C}_{5} \mathrm{~N}_{3}$ & $\mathrm{NaClO}_{4}$ & $\begin{array}{c}\text { Carbon } \\
\text { Gold } \\
\text { Platinum }\end{array}$ & $\begin{array}{l}-1.065 \\
-1.059 \\
-1.059 \\
\end{array}$ & $\begin{array}{l}-1.008 \\
-0.994 \\
-1.008 \\
\end{array}$ & $\begin{array}{l}-1.036 \\
-1.027 \\
-1.036 \\
\end{array}$ & $\begin{array}{l}57 \\
65 \\
57 \\
\end{array}$ \\
\hline $\mathrm{C}_{5} \mathrm{H}_{6} \mathrm{~N}-\mathrm{C}_{5} \mathrm{~N}_{3}$ & $\mathrm{TBAClO}_{4}$ & $\begin{array}{c}\text { Carbon } \\
\text { Gold } \\
\text { Platinum } \\
\end{array}$ & $\begin{array}{l}-1.097 \\
-1.090 \\
-1.097 \\
\end{array}$ & $\begin{array}{l}-1.035 \\
-1.040 \\
-1.032 \\
\end{array}$ & $\begin{array}{l}-1.066 \\
-1.065 \\
-1.065 \\
\end{array}$ & $\begin{array}{l}61 \\
50 \\
65 \\
\end{array}$ \\
\hline $\mathrm{C}_{10} \mathrm{H}_{8} \mathrm{~N}-\mathrm{C}_{5} \mathrm{~N}_{3}$ & $\mathrm{LiClO}_{4}$ & $\begin{array}{c}\text { Carbon } \\
\text { Gold } \\
\text { Platinum }\end{array}$ & $\begin{array}{l}-0.949 \\
-0.942 \\
-0.935\end{array}$ & $\begin{array}{l}-0.895 \\
-0.889 \\
-0.885\end{array}$ & $\begin{array}{l}-0.922 \\
-0.915 \\
-0.910\end{array}$ & $\begin{array}{l}53 \\
53 \\
50\end{array}$ \\
\hline $\mathrm{C}_{10} \mathrm{H}_{8} \mathrm{~N}-\mathrm{C}_{5} \mathrm{~N}_{3}$ & $\mathrm{NaClO}_{4}$ & $\begin{array}{c}\text { Carbon } \\
\text { Gold } \\
\text { Platinum }\end{array}$ & $\begin{array}{l}-0.977 \\
-0.974 \\
-0.980\end{array}$ & $\begin{array}{l}-0.926 \\
-0.925 \\
-0.914\end{array}$ & $\begin{array}{l}-0.951 \\
-0.949 \\
-0.947\end{array}$ & $\begin{array}{l}51 \\
49 \\
66\end{array}$ \\
\hline $\mathrm{C}_{10} \mathrm{H}_{8} \mathrm{~N}-\mathrm{C}_{5} \mathrm{~N}_{3}$ & $\mathrm{TBAClO}_{4}$ & $\begin{array}{l}\text { Carbon } \\
\text { Gold } \\
\text { Platinum }\end{array}$ & $\begin{array}{l}-1.019 \\
-1.002 \\
-1.014\end{array}$ & $\begin{array}{l}-0.957 \\
-0.949 \\
-0.957\end{array}$ & $\begin{array}{l}-0.988 \\
-0.975 \\
-0.985\end{array}$ & $\begin{array}{l}62 \\
53 \\
57\end{array}$ \\
\hline
\end{tabular}

${ }^{*}$ Recorded at $50 \mathrm{mVs}^{-1}$. 
Table 4: Kinetic data (heterogeneous rate constants, $k_{s}$ ) and diffusion coefficients (D) for reduction of the tricyanovinlyated products at carbon $\left(\mathrm{k}_{\mathrm{s}}{ }^{\mathrm{C}}\right)$, platinum $\left(\mathrm{k}_{\mathrm{s}}^{\mathrm{Pt}}\right)$ and gold $\left(\mathrm{k}_{\mathrm{s}}{ }^{\mathrm{Au}}\right)$ electrodes in $0.1 \mathrm{M}$ perchlorate based electrolytes. For the $\mathrm{C}_{4} \mathrm{H}_{4} \mathrm{~N}-\mathrm{C}_{5} \mathrm{~N}_{3}$ compound the transfer coefficients $(\alpha)$ appear in brackets.

\begin{tabular}{|c|c|c|c|c|c|}
\hline \multirow[t]{2}{*}{ Substrate } & Cation & $\mathrm{k}_{\mathrm{s}}^{\mathrm{C}}$ & $\mathrm{k}_{\mathrm{s}}^{\mathrm{Au}}$ & $\mathrm{k}_{\mathrm{s}}^{\mathrm{Pt}}$ & $\mathrm{D}$ \\
\hline & & $\mathrm{cm} \mathrm{s}^{-1}$ & $\mathrm{~cm} \mathrm{~s}^{-1}$ & $\mathrm{~cm} \mathrm{~s}^{-1}$ & $\mathrm{~cm}^{2} \mathrm{~s}^{-1}$ \\
\hline \multirow[t]{3}{*}{$\mathrm{C}_{4} \mathrm{H}_{4} \mathrm{~N}-\mathrm{C}_{5} \mathrm{~N}_{3}$} & $\mathrm{Li}^{+}$ & $5.6 \times 10^{-3}(0.12)$ & $6.5 \times 10^{-3}(0.12)$ & $4.3 \times 10^{-3}(0.12)$ & $3.8 \times 10^{-5}$ \\
\hline & $\mathrm{Na}^{+}$ & $4.7 \times 10^{-3}(0.13)$ & $4.9 \times 10^{-3}(0.12)$ & $3.0 \times 10^{-3}(0.11)$ & \\
\hline & $\mathrm{TBA}^{+}$ & $3.6 \times 10^{-3}(0.10)$ & $3.2 \times 10^{-3}(0.10)$ & $2.7 \times 10^{-3}(0.10)$ & \\
\hline \multirow[t]{3}{*}{$\mathrm{C}_{5} \mathrm{H}_{7} \mathrm{~N}-\mathrm{C}_{5} \mathrm{~N}_{3}$} & $\mathrm{Li}^{+}$ & $1.1 \times 10^{-2}$ & $2.3 \times 10^{-2}$ & $1.3 \times 10^{-2}$ & $1.1 \times 10^{-5}$ \\
\hline & $\mathrm{Na}^{+}$ & $1.3 \times 10^{-2}$ & $2.5 \times 10^{-2}$ & $1.1 \times 10^{-2}$ & \\
\hline & $\mathrm{TBA}^{+}$ & $1.2 \times 10^{-2}$ & $1.9 \times 10^{-2}$ & $1.1 \times 10^{-2}$ & \\
\hline \multirow[t]{3}{*}{$\mathrm{C}_{10} \mathrm{H}_{8} \mathrm{~N}-\mathrm{C}_{5} \mathrm{~N}_{3}$} & $\mathrm{Li}^{+}$ & $1.6 \times 10^{-2}$ & $2.1 \times 10^{-2}$ & $1.2 \times 10^{-2}$ & $2.4 \times 10^{-5}$ \\
\hline & $\mathrm{Na}^{+}$ & $1.7 \times 10^{-2}$ & $3.0 \times 10^{-2}$ & $2.1 \times 10^{-2}$ & \\
\hline & $\mathrm{TBA}^{+}$ & $2.2 \times 10^{-2}$ & $2.9 \times 10^{-2}$ & $1.2 \times 10^{-2}$ & \\
\hline
\end{tabular}


Figure 1 (a)

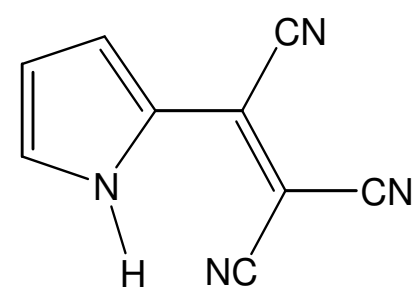


Figure 1(b)

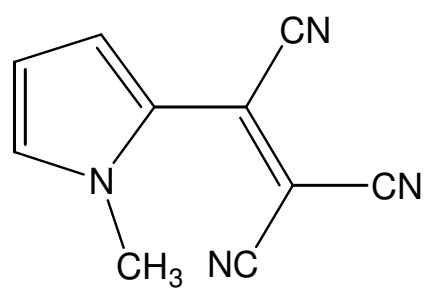


Figure 1(c)

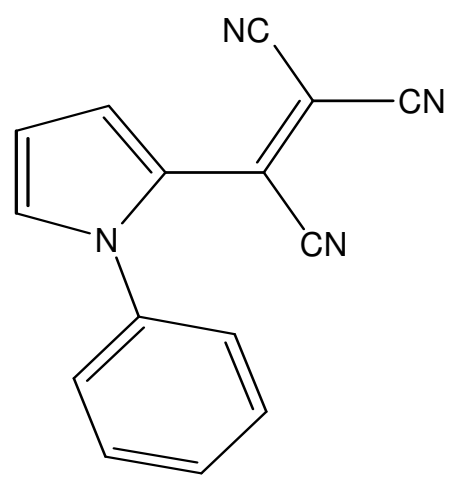


Figure 2(a)

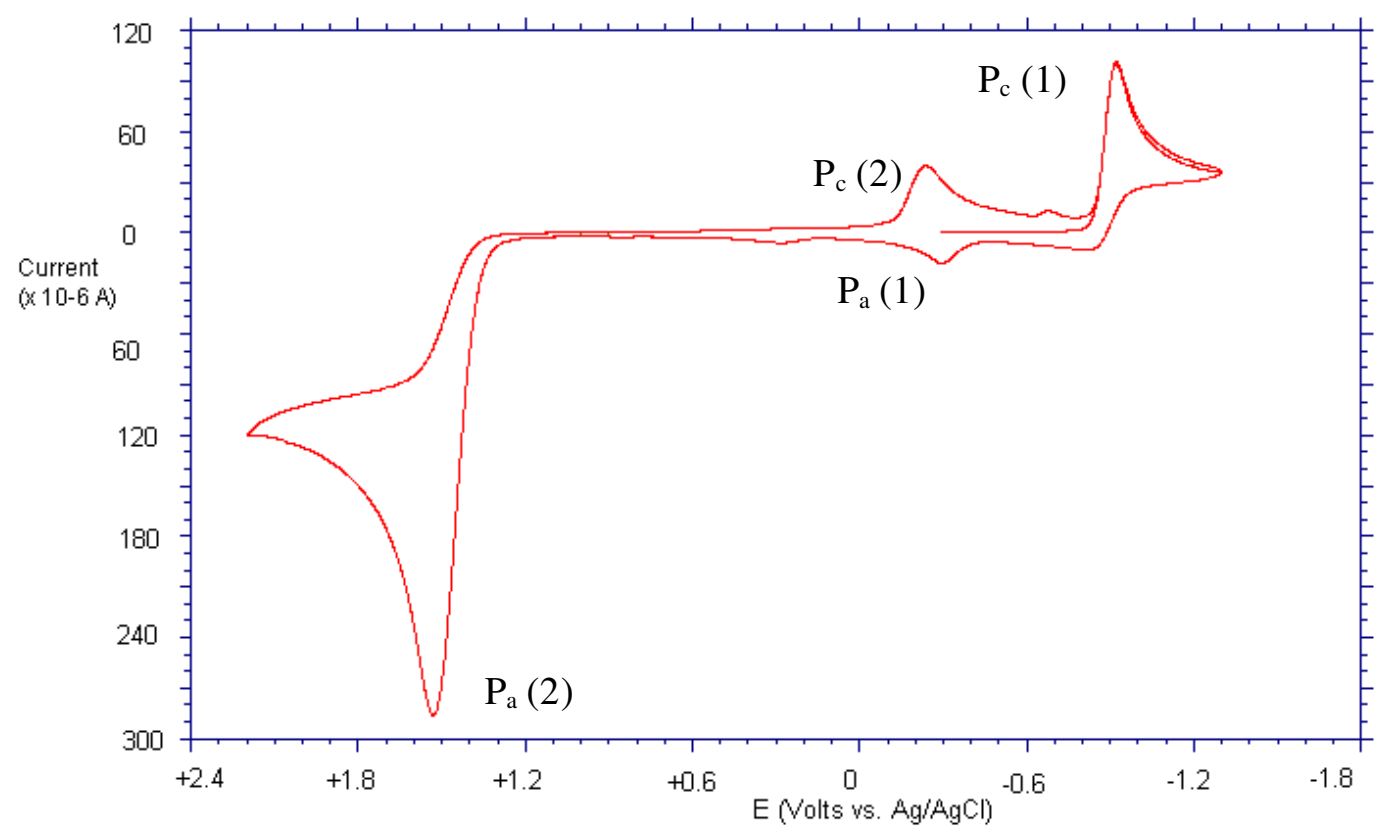


Figure 2(b)

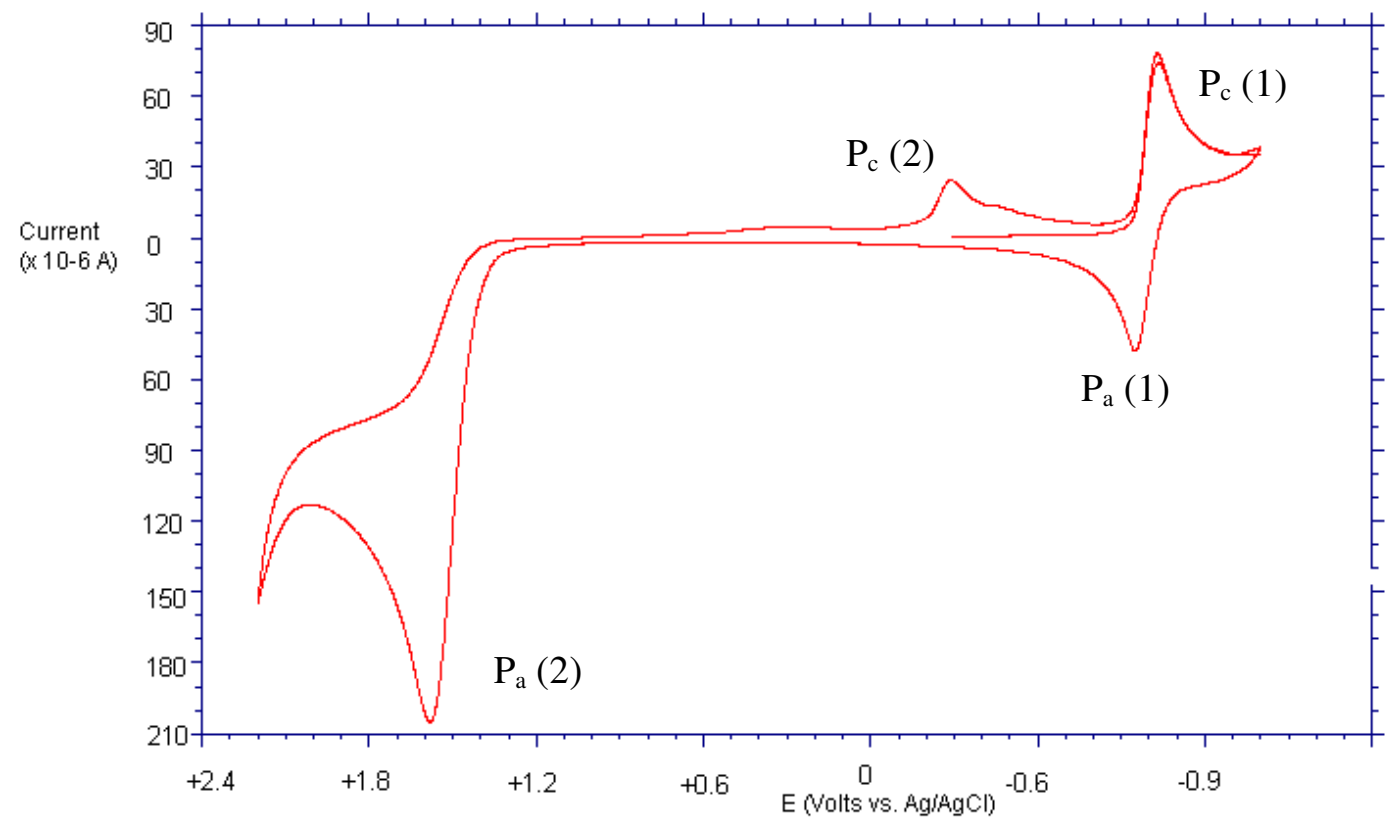


Figure 2(c)

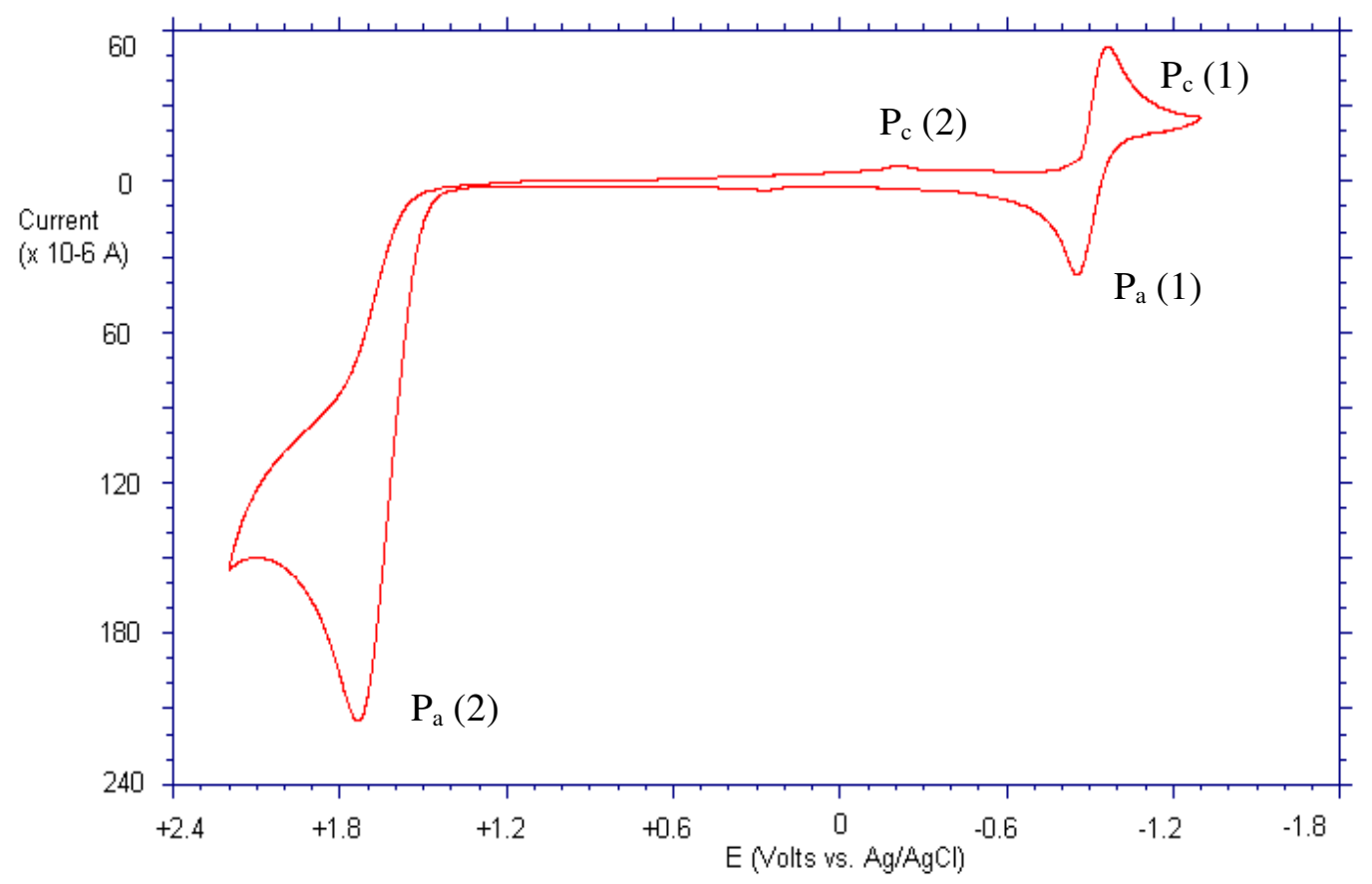


Figure 3(a)

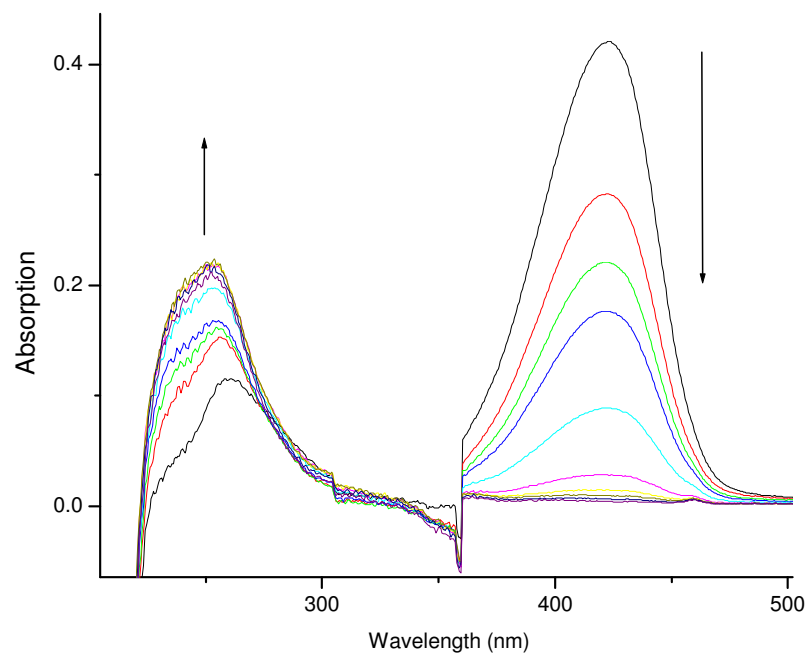


Figure 3(b)

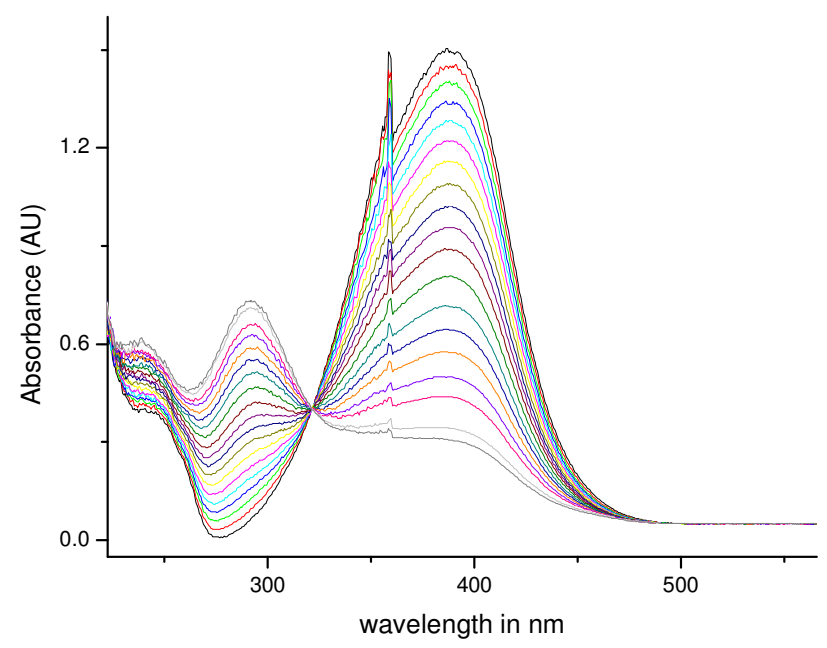


Figure 3(c)

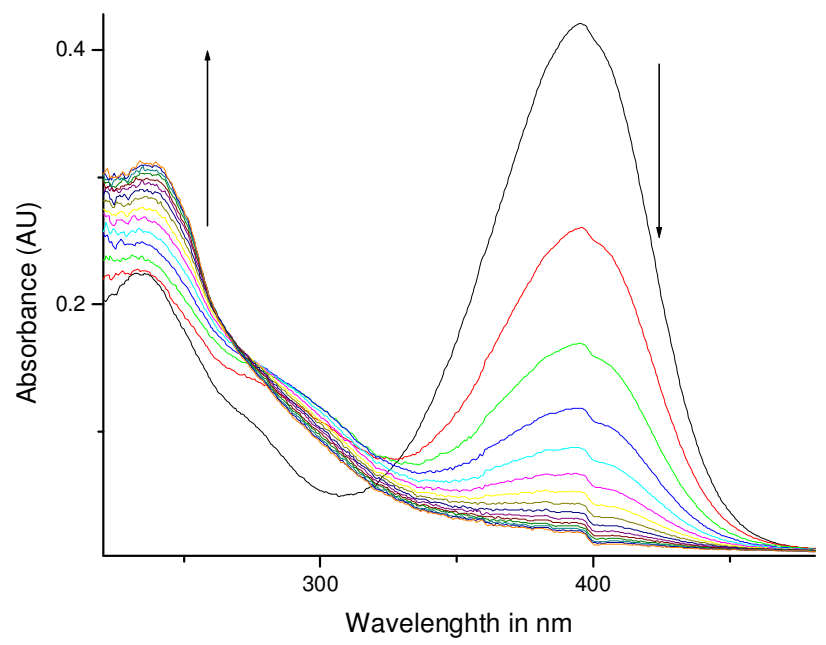

